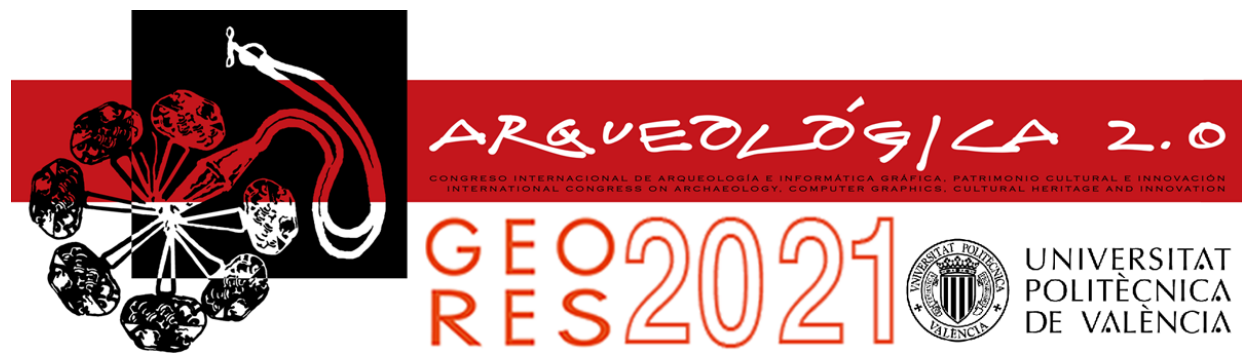

\title{
QANATS AS AN ENDANGERED TRADITIONAL HYDRAULIC HERITAGE. AN INTEGRATED METHODOLOGY FOR DOCUMENTING, RESTORING AND REUSING AN ANCIENT IRANIAN QANAT
}

\author{
Paola Branduinia, ${ }^{a}$, Federico Zainab, ${ }^{b}$ Fereshteh Zavvaria, Yasaman Nabati Mazloumi ${ }^{b}$ \\ ${ }^{a}$ Department of Architecture, Built Environment and Construction Engineering, Polytechnic University of Milan, P.zza Leonardo Da Vinci \\ 3, 20133 Milano, Italy. paola.branduini@polimi.it; fereshteh.zavvari@mail.polimi.it \\ ${ }^{\mathrm{b}}$ Department of History and Cultures, University of Bologna, P.zza San Giovanni in Monte 4, 40124 Bologna, Italy. \\ federico.zaina@unibo.it; yasaman.nabati@studio.unibo.com
}

\begin{abstract}
:
Qanats represented a major technological solution for water supply in arid and semi-arid regions for millennia. Thanks to their multiple social and economic benefits, qanat-like systems spread from Iran through the Middle East in most of the arid and semi-arid regions of the world. In recent years, this valuable traditional hydraulic technology has been neglected in the preservation and reuse due to the lack of management as well as the lack of legal support. This precious heritage and sustainable water supply system according to their sustainable structural features has been replaced by modern water collection and management systems such as dams and other hydroelectric infrastructures along with new pumping technologies. Nevertheless, there is a growing consensus on the number of short, medium and long-term issues emerging from these systems including pollution and other environmental damages, regional conflicts, political pressures as well as their limited lifetime and structural instability. The purpose of this paper is to show qanats as an example of endangered heritage which could also represent a sustainable and clean technology. To do so, we apply a multi-disciplinary perspective integrating archaeological, architectural, sociological and conservation methodologies on a specific case study from the Tabriz region in Northwest Iran: the "No-Ras" qanat.
\end{abstract}

Keywords: Iran, qanat, urban-rural communities, traditional hydraulic technology, remote-sensing, endangered heritage, community perception, restoration and repairing

\section{Introduction}

Qanats have represented a major technological advance and solution for water supply in arid and semi-arid regions for millennia (Goblot, 1979; Yazdi and Khaneiki, 2017; Khaneiki, 2019) and their history is entangled with the emergence of several civilizations over time.

Archaeological research recognized two main areas of the Middle East as the cradle of qanats system (Wilkinson \& Rayne, 2010): the Zagros mountain in the west of Iran (Lightfoot, 1997; Ur, 2005) and southeast Arabia (Al Tikriti, 2002; Lightfoot, 2000; Wikander, 2000). The former location is also supported by textual evidence provided by the Neo-Assyrian chronicles of King Sennacherib (Dalley, 2013; Salvini, 2001) which brought specialized artisans to Assyria for replicating the system to provide water to the main cities of the empire.

Thanks to their multiple social and economic benefits, qanat-like systems spread throughout the Middle East and beyond in most of the arid and semi-arid regions of the world, from the Mediterranean (Gerrard \& Gutiérrez,
2018; Lofrano et al., 2013) to Central and South America (Beekman, Weigand, Pint, Zotz, \& Pin, 1996), and from China and the Far East (Hu, Zhang, \& Liu 2012; Luo et al., 2014) to Africa (Briant, 2001; Lightfoot, 1997). Although it might be argued that there was a major decline in the construction of qanats after their heyday during the Sasanian and Islamic periods, historical sources suggest that they continued to be built and used until at least the 19th century CE (Hütteroth, 1990; Wilkinson \& Rayne, 2010). Today, qanats are documented in 34 countries around the world (Mostafaeipour, 2010). In terms of quantity and dimensions, Iran represents the richest country with almost 24,000 qanats mostly clustered in the arid and semi-arid dry steppe areas in the Yazd, Fars and Isfahan provinces (Fig. 1). Several thousand are also attested in the Alborz and Zagros upland areas along with other traditional hydraulic facilities.

Nowadays, an increasing number of qanats are being replaced by modern water collection and management systems such as dams and other hydroelectric infrastructures along with new pumping technologies (Bensi, 2020). However, there is a growing consensus on 
the multiple, often irreversible, issues inherent or caused by most of these modern systems including pollution and other environmental damages, regional conflicts, political pressures as well as their limited lifetime and structural instability (Shoup, 2006; Strzepek, Yohe, Tol, \& Rosegrant, 2008; White, 1988; Wieland \& Mueller, 2009). The considerable negative impact on the planet of these water infrastructures has also recently led various scholars to include them among the global trends of the Anthropocene (Steffen, Broadgate, Deutsch, Gaffney, \& Ludwig, 2015).

Currently, we continue to witness the gradual abandonment of many qanats partly due to the lack of awareness of local populations and the loss of skilled personnel, management and maintenance. Additionally, human-induced activities such as urban sprawl and growing agricultural fields are threatening these ancient water systems worldwide (Khaneiki, 2019; Saberi, 2016). In this regard, over the last decade, an increasing number of studies underlined how the conservation and use of qanats integrated with modern clean methodologies, can play a key role from an economic, environmental, social and cultural point of view (Jomehpour, 2009; Khaneiki, 2019; Yazdi \& Khaneiki, 2017).

The purpose of this paper is to show qanats as an example of endangered heritage which could also represent a sustainable and clean technology. To do so, we apply a multi-disciplinary perspective integrating archaeological, architectural, and sociological and conservation methodologies on a specific case study from the Tabriz region in Northwest Iran: the "No-Ras" qanat.

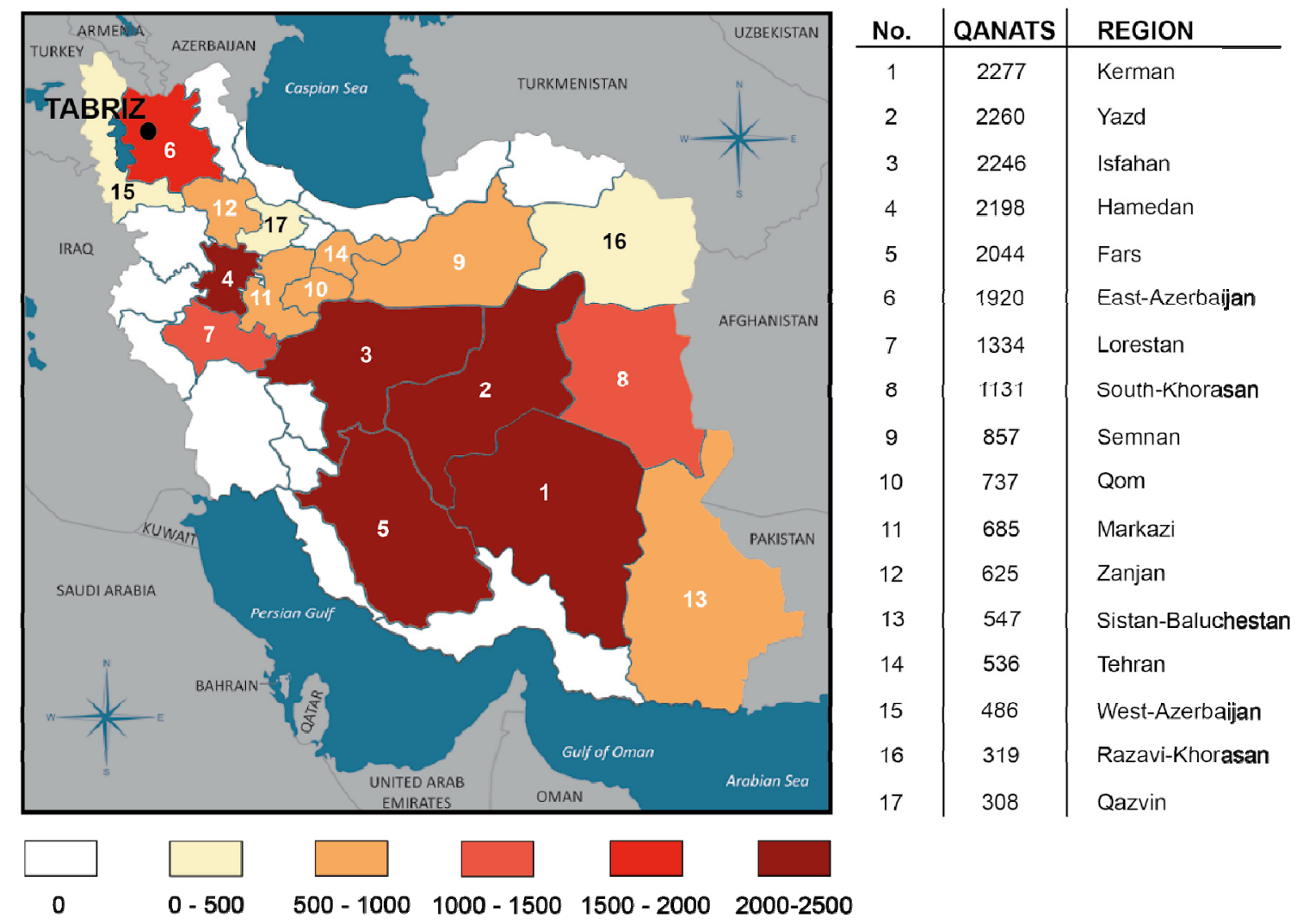

Figure 1: Approximate distribution of qanats in Iran by region and the location of Tabriz (modified after Maleki \& Khorsandiaqaei, 2016).

\section{Current issues}

The current state-of-the-art highlighted five intertwined key-issues revolving around qanats in Iran.

\subsection{Water shortage}

The most pressing issue regards the water shortage. Indeed, arid and semi-arid regions in Iran and beyond are facing severe water scarcity due to natural and anthropogenic factors (Hosseini et al., 2010; Weingartner, 2007). While representing a sustainable and clean solution to solve such a major issue, during the last 20 years the Iranian Ministry of Energy (2005) gradually excluded qanats from the national water supply system investments which led to a dramatic drop in their use. Alternatively, modern hydraulic infrastructures such as dams and other facilities came to force. However, while providing substantial economic benefits, these infrastructures require regular maintenance and have a finite lifespan (Wieland \& Muller, 2009). Furthermore, the construction of dams causes the dislocation of thousands of people, permanent loss of soil fertility and widespread destruction of cultural and natural heritage (Marchetti et al., 2019; Marchetti, Bitelli, Franci, \& Zaina 2020).

\subsection{Mismanagement and lack of documentation}

One of the main causes of water shortage (2.1) in Iran is the mismanagement and lack of control of the hydraulic resources throughout the country. In the case of the qanats, to date, a complete documentation (both in use and abandoned) is missing (Maleki \& Khorsandi aqaei, 2016). Although scattered initiatives provided glimpses on their distribution and the state of preservation in different 
provinces such as Tehran (Ebadati \& Hosseini, 2018), Mashhad (Hosseini et al., 2010) or Sabzevar (Estaji \& Raith, 2016), such a huge endeavour could be accomplished only through a wider project promoted or in collaboration with national bodies such as the Ministry of Energy.

\subsection{Loss of knowledge and technical skills}

The lack of control and mismanagement (2.2) result in a decrease in the use of qanats. This is strictly connected with the loss of specific technical skills and the in-depth topographic and geomorphologic knowledge needed to build the major hydraulic feature. This phenomenon is particularly apparent outside the most popular areas such as Yazd, where the gradual abandonment of qanats in favour of wells backed by diesel pumps, resulted in the decrease of skilled artisans (Mostafaeipour, 2010).

\subsection{Lack of awareness}

The lack of control and mismanagement (2.2), along with the loss of specific personnel in charge of building qanats (2.3) lead to the low or total absence of awareness toward this traditional water infrastructure among local communities throughout Iran (Balali, Keulartz, \& Korthals, 2009). According to De Chatel (2005), this lack of awareness is also tightly related to the idea that the modern hydraulic infrastructures will provide endless water supply, thus concealing the reality of water shortage.

\subsection{Underestimation of qanats as cultural heritage}

Lack of awareness (2.4) also means a drop in the people's perception of the qanats as an integral part of their culture, society and economy. Qanats represent the oldest, most widespread and monumental traditional technology still in use in Iran. These factors contributed to recognize their outstanding value and to inscribe a small number of qanats (11) within the UNESCO World Heritage List (WHL). However, this is a fraction of the 24,000 in the country, many of which are as important and monumental as those within the WHL. Qanats are also protected by Iranian law (Iranian Dept. of Environment, arts. 1 and 12).

However, recent research (Hosseini et al., 2010) highlighted the widespread disrespect for the current legislation often in favour of unregulated urban expansion, or the conversion of land for more profitable uses.

\section{Aims and methods}

Despite these issues, qanat still represents a clean and sustainable traditional hydraulic technology having the potential to 1. Replace modern polluting water-related infrastructures (dams etc.), 2. Be recognized as an important part of the national heritage (beyond the already well-recognized areas).

Therefore, in this paper by analyzing the No-Ras qanat as a case study, located in the Tabriz region, we investigate the twofold potential of qanats to contribute solving the above-mentioned issues. In particular, our research is underpinned by the following research questions:
1) How did the territory of the Tabriz area change through time? What is its relation with the No-Ras qanat?

2) What kind of issues and threats affected the No-Ras qanat during the last decades?

3) How did the perception of the local communities towards the No-Ras qanat change through time?

4) What kinds of recommendations can be proposed to fulfil the twofold potential of the qanats?

The first group of research questions will allow tackling issue 2.1, the second one will address issues 2.2 and 2.3, while research question three will allow tackling issues 2.4 and 2.5. The last research question has been designed to provide solutions and to foster the potential of qanats as a useful traditional hydraulic infrastructure and an important part of the country's heritage. The methodology applied to answer these questions integrates established approaches taken from archaeology and landscape architecture: 1) Territorial and land-use analysis (3.1); 2) Multi-temporal remote sensing analysis of the damages $(3.2)$; 3) Structural analysis of the qanat $(3.3)$; 4) Perception and awareness analysis (3.4).

These types of analysis allow a comprehensive study of the qanat as a traditional hydraulic technology useful for addressing the aforementioned five issues illustrated (section 2). We have applied a multi-scalar methodology, consisting in the analysis of the whole geographic context related to qanat, starting from the regional and urban one (analysis 1), to the area of qanat (analysis 2), moving to the qanat itself (analysis 3 ) and eventually to the relationship between qanat and local communities (analysis 4).

\subsection{Territorial and local land-use analysis}

Popular perceptions as well as the majority of scientific research, usually associate qanats to the arid and semiarid highlands of central Iran. However, as shown in Figure 1, several thousand others are also found in the more temperate valleys and uplands of the north and north-western parts of the country. While in the past, these qanats integrated the water flow provided by the numerous rivers, in recent years the maintenance costs together with the emergence of new hydraulic technologies caused their gradual abandonment and slow structural decay. Among those, the No-Ras qanat, located in the south-eastern outskirts of Tabriz, represented an important water supply system for the city (Afshar, 1971). Despite the efforts of the local farmers to preserve it, during the last twenty years, urban and regional development projects severely damaged the overall structure including many wells, part of the gallery and the outlet.

To better understand the changes in the No-Ras qanat area, territorial and land-use analysis will be carried out. This type of analysis allow to identify the transformation of agricultural lands into residential areas in the qanat buffer zone and the growth of unconventional semiindustrial land-uses as well as to integrate the results of the multi-temporal analysis. The former consists of the analysis of the key environmental and urban elements influencing the development of Tabriz and the surrounding area. The land-use analysis will be conducted using satellite imagery and governmental 
sources as well as the region observation to understand the current use of the area within the qanat buffer zone.

\subsection{Multi-temporal remote sensing analysis of the damages}

In order to answer the second research question, we applied a multi-temporal remote sensing analysis of the damages to the case study. The identification of damages to the No-Ras qanat was conducted for the last 20 years taking into account four-time frames: 2003, 2008, 2013, 2020. These periods have been selected for three reasons:

1) High-quality open-access satellite imagery of the region has become available from 2003 onwards.

2) From the early 2000s onwards, Tabriz and its periphery experienced a vast and unregulated urban sprawl which also affected the No-Ras qanat.

3) Within the considered chronological time span, the four periods selected correspond to the main phases of upheavals and disturbance.

Remote sensing and satellite imagery has become a key methodology in the wider field of cultural heritage management (Lasaponara \& Masini 2012). Sources for remote sensing analysis may include different spatial datasets of historical aerial and satellite imagery, often available through open-access or on-purchase online platforms and websites (Zaina, 2019). The application of remote sensing to cultural heritage risk assessment has recently become popular in the Middle East (Agapiou, Lysandrou, \& Hadjimitsis 2017; Agapiou, Lysandrou, \& Hadjimitsis 2020; Cunliffe, 2014; 2016; Hammer, Seifried, Franklin, \& Lauricella 2018; Lauricella, Cannon, Branting, \& Hammer 2017; Marchetti et al., 2019; Marchetti, Bitelli, Franci, \& Zaina 2020; Richardson, 2011; Zaina, 2019). However, no attempts have been done so far for documenting and monitoring the state of preservation of qanats through time. The multi-temporal remote sensing analysis conducted consists of three steps: 1. Data collection, 2. Data processing; 3. Results.

Data collection: For the first step, spatial data related to the No-Ras qanat and geographic data (satellite imagery) have been collected from hardcopy publications and online platforms and then organized in a QGIS environment. Hardcopy publications (Haeri, 2007; Hosseini et al, 2010; Jomepour, 2009; Kabir, 2008; 2010; Shahabadi \& Olfati, 2009; Tabatabaei \& Khazimeh Nejad, 2019) allowed to obtain spatial information such as the location of the No-Ras qanat, the position and dimension of the wells and its path in the outskirt of Tabriz, and to generate an attribute table with non-spatial data including the types of damages and their extension. The official buffer zone of the qanat, available through the hardcopy guidelines issued by the Ministry of Energy (2018), provided the limit of the area of the No-Ras qanat under analysis. This ranges between 1 and $1.5 \mathrm{Km}$ based on the geomorphology of the area and the flow rate of the mother well. In the case of the No-Ras qanat, the buffer zone is 1 $\mathrm{Km}$. Geographic data, consisting of high-resolution openaccess satellite imagery of the four different periods, were collected from Google Earth Pro $®$ and the USGS platform (Table 1). The highest quality images (in terms of resolution and visibility) were selected to identify the types of damages considering also the seasonal changes which can greatly influence their identification. It must be pointed out that $30 \%$ of 2003 satellite imagery of the No-Ras qanat did not provide accurate data, thus slightly affecting the damage assessment. For example, we have excluded images that presented visibility problems caused by atmospheric agents (i.e. clouds).

Table 1: Detailed description of the satellite images.

\begin{tabular}{|c|c|c|c|}
\hline Dates & Satellite & Resolution & Source \\
\hline $\begin{array}{l}5-11-2020 \text { to } \\
9-21-2020\end{array}$ & $\begin{array}{l}\text { Maxar® } \\
\text { satellites }\end{array}$ & $0.3-15 \mathrm{~m}$ & $\begin{array}{l}\text { Google Earth } \\
\text { Pro® } \\
\text { USGS Earth } \\
\text { Explorer }\end{array}$ \\
\hline $\begin{array}{l}3-15-2013 \text { to } \\
9-1-2013\end{array}$ & $\begin{array}{c}\text { Maxar® } \\
\text { satellites } \\
\text { CNES } \\
\text { Airbus }\end{array}$ & $0.3-15 \mathrm{~m}$ & $\begin{array}{c}\text { Google Earth } \\
\text { Pro } \AA\end{array}$ \\
\hline $\begin{array}{c}6-2-2008 \text { to } \\
6-7-2008\end{array}$ & $\begin{array}{l}\text { Maxar® } \\
\text { satellites }\end{array}$ & $0.3-15 \mathrm{~m}$ & $\begin{array}{c}\text { Google Earth } \\
\text { Pro }{ }^{\circledR}\end{array}$ \\
\hline $8-8-2003$ & $\begin{array}{l}\text { Maxar® } \\
\text { satellites }\end{array}$ & $0.3-15 \mathrm{~m}$ & $\begin{array}{c}\text { Google Earth } \\
\text { Pro® }\end{array}$ \\
\hline
\end{tabular}

Data processing: We conducted a semi-automatic classification of the different types of damages and their development over the last 20 years cross-correlating the spatial and geographic data in QGIS. The first part consisted of the visual detection of the risks and damages within the buffer zone area. Then we automatically calculated the area through QGIS.

Results: The last step consisted of the analysis of the results of the damages to the No-Ras qanat. These results allowed us to develop an ad hoc framework of the different types of damages to the No-Ras qanat and the factors triggering each type of damage (see below).

A kind of groundwater extraction, a qanat consists of an underground gallery which conveys water to the surface, and several vertical shaft-wells to bring the water for diverse uses. Soils excavated from the shafts are piled around their collar thus creating a line of short mounds (Abbasnejad, Abbasnejad, Derakhshani, \& Hemmati Sarapardeh, 2016; Bensi, 2020; Khaneiki, 2019; Yazdi \& Khaneiki, 2017). Unlike an aqueduct, a qanat is a dynamic system which cuts through the soil and advances into the saturated area underground (Yazdi \& Khaneiki, 2017). The critical issue in conducting a risk assessment of qanats is that only the piles around the vertical shafts (showing the direction of the qanat on the ground) are visible from above. This fact made necessary to develop a proper framework to ensure a comprehensive classification of risks and damages.

Recent studies have tried to develop several types of classification of risks and damages to the cultural heritage focusing on the triggering factors, types of risks and actions (ICCROM, 2016; ICOMOS, 2000; Lopez, 2016; Palumbo, 2000; Stovel, 1998; UNESCO, 2010; Zaina, 2019). Our framework has been designed by integrating and enriching the structure of the previous examples provided by Zaina (2019), Lopez (2016) and ICCROM (2016). We developed a tailor-made framework focusing on qanats (while previous studies were designed around general cultural heritage) including a double-factor scheme divided between human-induced and naturalinduced factors (Fig. 2). Each of these factors may be 
related to different drivers meaning a condition, a necessity or a decision causing one or more subsequent processes (in our case the threats). Threats are defined as one or more risks generally related to one specific driver, even though often possibly connected to more than one, and eventually generating a specific set of physically dangerous actions (Zaina, 2019). For our risk assessment, we identified threats such as construction, agriculture and abandonment, erosion and earthquake (Fig. 2). The next tier of the risks typology is represented by the physical actions which are any kind of activities jeopardizing the qanats. For example buildings, roads, canals and levelling activities are the types of actions related to the construction threat. Each action or more interrelated actions may put the qanat in danger causing a specific impact leading to its total of partial destruction. Impacts are the influence of the situation in which they can strongly affect a site as a direct result of an action (ICCROM, 2016). Buildings as an action resulted by human-induced drivers and threats can result in vegetation loss of the area which can be one of the main reasons in qanat destructions (Abbasnejad, Abbasnejad, Derakhshani, \& Hemmati Sarapardeh, 2016; Khaneiki, 2019; Saberi, 2006).

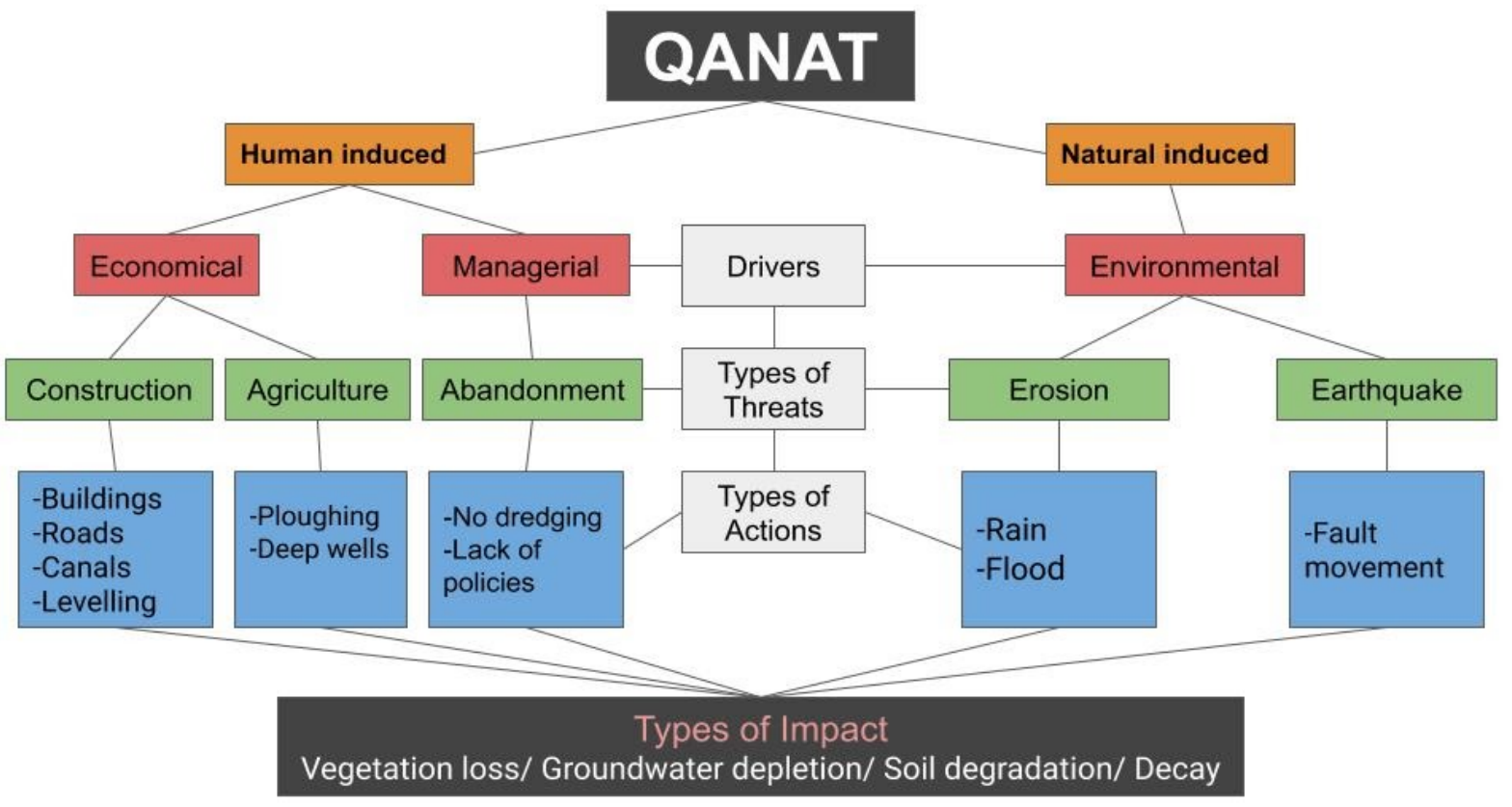

Figure 2: The Double-factor framework of risks and damages to qanats, modified after Zaina, 2019.

\subsection{Structural analysis}

As a sustainable water supply structure, any changes or damages in the qanat structure affect its water flowing rate. The structure consists of three main parts (gallery, shaft-wells, and outlet). These extend from the qanat starting point, the mother-well to the structure's endpoint, the outlet, corresponding to about $3.5 \mathrm{~km}$.

The land-use changes along the No-Ras qanat route area are directly or indirectly responsible for major changes in the No-Ras qanat structure. However, compared to the last ten years, the amount of water production has been significantly reduced. For instance, the northern area of FathAbad garden's is challenging with a water shortage based on the interviews. Therefore a structural analysis conducted through ground-truthing activities between 2019 and 2020 allowed to map the state of preservation of each part of the No-Ras qanat (gallery, shaft-wells, and outlet) and to propose solutions for restoration and maintenance.

\subsection{Perception and awareness analysis}

Perception and awareness analysis is crucial for answering the third research question. For centuries, since the qanat was one of the main methods of supplying water, and human life depended on it, people were fully aware of this structure's value and worked to maintain it.
Therefore, people's awareness and knowledge about the qanat as sustainable water supplying structure plays an essential role in the restoration, maintenance, and reconstruction of the qanats. Specifically, in the case of the No-Ras qanat, we deal with an area the economy of which was based on agriculture and animal husbandry and the water supplied through the qanats and seasonal rivers. Therefore local communities were fully aware of the value of this structure and took care of its maintenance. In the last decades, after migration of native population and expansion of Tabriz, this area has been included among its suburbs. New local people are slowly forgetting the relevance of qanats for many intertwined reasons. The region also experienced new semi-industrial land-uses in the last decade, which have turned its rural face.

The analysis of the social fabric of the regional population allowed to identify five groups of people: local farmers, old immigrant farmers, new immigrants, factories employees, new owners. The perception and awareness of these five groups have been analyzed using semi-structured interviews.

\section{The case-study: No-Ras qanat}

The earliest evidence of the presence of qanat in the Tabriz area can be traced back to the 13th century CE (AI 
Kashani, 1968). The historical text of "History of Al-Jaito", dating to this period, testified the numerous hydraulic activities carried out by Khajeh Rashid Al-Din Fazlullah during the Mongolian rule over the region. In Al Kashani's (1968) words "In the past, the region of FathAbad was just dry mountains, but now every part of it is a paradise adorned with all kinds of trees and the rivers and the green meadows". Rashid al-Din Fazlullah's plan included the improvement of water supply in the region. To do so, he brought farmers and "moqanni" (Artisan specialized in the digging, cleaning, and repairs of qanats) from Yazd (in central Iran). In addition, due to the lack of local rural population, he entrusted foreigners with the creation of gardens, ploughing fields and other water-related infrastructures (Petrushevsky, 1978). "Rabe-e Rashidi" endowment letter provides a detailed explanation of the conditions of the qanats that flowed to the villages (Minovi
\& Afshar, 1972). This document highlights how the construction of the qanat was the result of his comprehensive geological knowledge of the region and the skills of the moqannis in building qanats (Al Khashani, 1968). The overall plan fostered the economic and social development of FathAbad region which became a prosperous rural residential area, with facilities and extended cultivated lands (Afshar, 1971). While the political situation in the region remarkably changed through time, the hydraulic system developed by Rashid Al-Din Fazlullah, including the No-Ras qanat, was maintained for almost seven centuries.

The "No-Ras" qanat length is about $3.5 \mathrm{~km}$ and runs from the slope of Sahand Mountain near the village of Chavan to the outlet located in the FathAbad garden (Fig. 3).

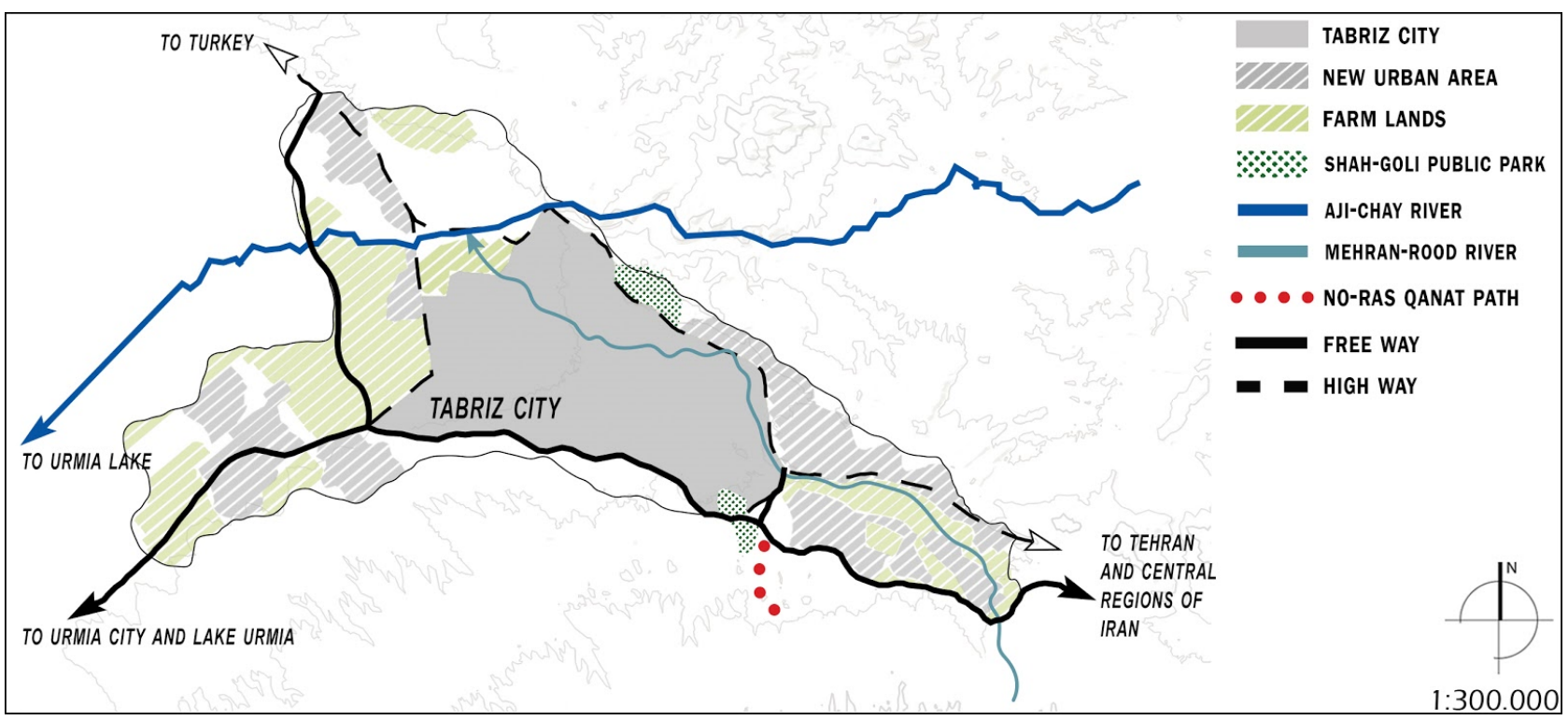

Figure 3: The Tabriz area and the No-Ras qanat.
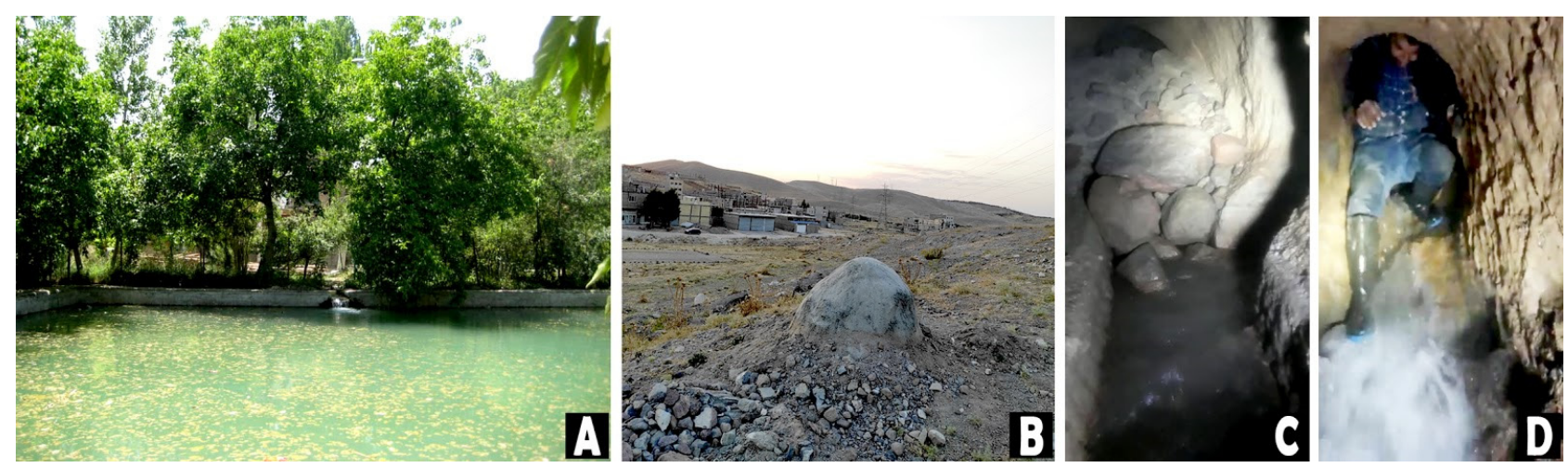

Figure 4: "No-Ras" Qanat. 4A. One of the water pools of the No-Ras qanat outside the garden for agricultural use; 4B. One of the blocked shaft-wells (photo taken in September 2020 by F. Zavvari); 4C. Part of the qanat canal that was destroyed by seasonal flood; $4 \mathrm{D}$. The uneven surface of the qanat channel (Photo taken in 2019 by the manager of the garden and the moqanni).

From the pool located inside the garden (Fig. 4a), the qanat water flow through the FathAbad village and the surrounding cultivated lands. The No-Ras qanat has 54 shafts (wells) including the mother well, located at a relatively regular distance of about $60 \mathrm{~m}$ (Fig. 4b). Only 11 of these wells can be recognized, and just four of them are accessible and open, while the rest are blocked with cement or concrete (Fig. 4b). Several shafts (wells) were destroyed by seasonal floods, which also affected part of the qanat gallery (Fig. 4c), while others were blocked by new owners or fenced within private buildings. The deepest shaft is the "Mother-well" which is about $49 \mathrm{~m}$. Due to the highly irregular morphology of the terrain, several more shaft-wells were dug to the same depth of the Mother-well to reach the underground gallery (Fig. 4d). 


\section{Results}

\subsection{Territorial and land-use analysis}

Tabriz is the capital and main centre of the East Azerbaijan province and the fifth most populous city of Iran. The urban centre is distributed over a large area ranging between $1200 \mathrm{~m}$ and $3800 \mathrm{~m}$ a.s.l. resulting in annual precipitations of about $230 \mathrm{~mm}$, with a maximum of $48.2 \mathrm{~mm}$ in winter and a minimum of $4 \mathrm{~mm}$ in spring and summer seasons. The average annual temperature in the study area is about $12.5^{\circ} \mathrm{C}$. The temperature often reaches $30{ }^{\circ} \mathrm{C}$ in summer and drops to $-0.5{ }^{\circ} \mathrm{C}$ in winter (De Martonne, 1941).

The No-Ras qanat is part of a complex environmental and urban system that centred on the city of Tabriz, the Zagros Mountains and Lake Urmia. These elements play a key role in shaping and modifying land-use in the region. With an area of more than $700 \mathrm{~km}^{2}$, Tabriz province is extended from the eastern limit of Tabriz city to Urmia Lake to the west. It is surrounded by the southern slopes of Mishow and Morow to the west, the Garadug Mountains to the north, and the northern slopes of Sahand Mountain to the south.

The environmental system of Tabriz province is characterized by natural elements such as rivers and mountains as well as human/natural made ecological green corridors. The riverine system is characterized by two main streams (Fig. 5a): 1) The Aji-Chay River, the most important river in the area, enters from the east and flows towards the west, and eventually discharges to the Urmia Lake; 2) The Mehran-Rood River passes inside the Tabriz city, from east to west, and then joins the AjiChay River at the city's western end. The mountain system occupies large parts of the city including (Fig. 5a) the Eynali Mount to the north and the Sahand Mountain range to the south. The topographic distribution of these mountains shaped Tabriz to a linear and longitudinal development. They played a prominent role as a natural landmark in the city's visual structure. Ecological green corridors (Fig. 5a) consist of regular or irregular open spaces. Natural or human-made vegetation has ecological and social efficiency.

The city of Tabriz is located in a strategic position that contributed to shaping its urban system (Fig. 5b). Since its foundation, it was placed at the cross-road between Azerbaijan, Turkey, and Iraq and it represented a gateway to the Ottoman Empire, Russia, and Europe for Iran and central and eastern Asian countries. Moreover, the city has been located along the "Silk Road" connecting Far East to Europe. The linear development of the urban layout of Tabriz brought it to include most of the surrounding villages and to turn much of the cultivated land into residential areas over time (Fig. 5b). Tabriz environmental and urban system highly influenced the overall organization of the city and land-use through time. At the south-eastern end of the city, 14 small towns and villages have been slowly incorporated into its urban system.

Farmlands, new residential neighbourhoods, industrial areas and a large university campus filled most of the empty areas and have been connected to the city centre through a web of roads, free-ways and high-ways (Fig. 6). Such major changes in the land-use also affected the area around the No-Ras qanat (Fig. 7). In particular, the units have been constructed throughout its path. Moreover, close to the FathAbad garden area, previously unoccupied lands within the buffer zone have been turned into sand and gravel mine, while both the gas pipeline and railway (to be completed in 2025) cut through the last stretch of the qanat. Other major changes include the development of the Tabriz-FathAbad and the TabrizChavan roads from earth paths to asphalt roads. The garden itself has been heavily affected by the construction of the freeway passing through it.

\subsection{Multi-temporal remote sensing analysis}

This framework resulted from the multi-temporal analysis conducted to identify the damages that occurred to the No-Ras qanat between 2003 and 2020. This analysis was performed by overlaying satellite imagery in four-time frames of 2003, 2008, 2013, 2020. Figure 8 shows the distribution of the risks and damages in the No-Ras qanat over time. In general, the analysis showed a gradual increase in damages between 2003 and 2020. Building construction represents the major physical action damaging the qanat and its buffer zone with a boost from 6.24 ha in 2003 to 19.89 ha in 2008 . The same trend has been observed for roads. Indeed, while 2.69 ha of the case study area was occupied by roads in 2003, this number has doubled twice, first in 2008 (4.49 ha), and then in 2013 (13.17 ha) eventually reaching 15.36 ha in 2020 . Although the presence of these infrastructures may not cause direct destruction of the qanat, the overall widespread urban sprawl in the proximity of the qanat resulted in vegetation loss and soil degradation, both having a direct impact on the buffer zone of qanat by jeopardizing the soil density around it and contributing to the collapse of the shaft-wells. The second most pervasive damage is levelling. While the steady increase of levelling activities in the area passed from 14 ha in 2003 and raised to 19.8 ha in 2008, it sharply increased to 29.95 ha in 2013 and jumped to 51.57 ha in 2020 . The entanglement of the physical actions is confirmed by the fact that almost all the areas levelled between 2003 and 2008, turned into roads or buildings between 2013 and 2020. While levelling caused vegetation loss within the buffer zone, the heavy machinery put pressure on the walls of the qanat gallery. A similar trend has been identified for ploughing. From having little impact in 2003, with no more than 5 ha in cultivated fields, the ploughed area has grown exponentially in almost twenty years reaching 45.66 ha in 2020 . As we mentioned before, soil degradation and vegetation loss can be the direct impact of ploughing and agricultural activity. Deep or semi-deep wells drilling can only be identified from 2003 to 2008 over an approximate area of 0.45 ha. Despite their seemingly small impact, these kinds of actions, mostly carried out for agricultural purposes, can cause substantial damages to the structure of the qanat.

Overall, the multi-temporal analysis demonstrated an increasing trend in all of the physical actions throughout the No-Ras qanat and its buffer zone. Currently, 201.39 ha out of 685 ha of the entire buffer zone have been damaged.

\subsection{Structural analysis}

The changes in the land-use heavily affected the structure of the qanat including the wells, the gallery and the outlet. At the regional level, a substantial reduction of the water 
flow from underground water including the No-Ras qanat has been observed. Locally, each of the abovementioned land-use changes caused major disturbances and damage to the qanat structure (Fig. 9). For example, the construction of the gas pipeline destroyed a $100 \mathrm{~m}$ long stretch of the qanat close to the outlet (Fig. 9b and 9c). Instead of repairing the damages, an artificial pipe was used to transfer the water to the outlet. Moreover, the heavy trucks and cargo vehicles passing close to the wells together with the digging the large and deep holes to collect sand and gravel highly affected the structural stability of the wells and the gallery (Fig. 9b and 9c). The same effect is caused by the widespread construction of residential and industrial buildings (often illegally) within the buffer zone and often close to the wells (Fig. 9b and 9c). Another major issue is the illegal drilling of deep or semi-deep wells which are used both to obtain freshwater and as for sewage discharge.

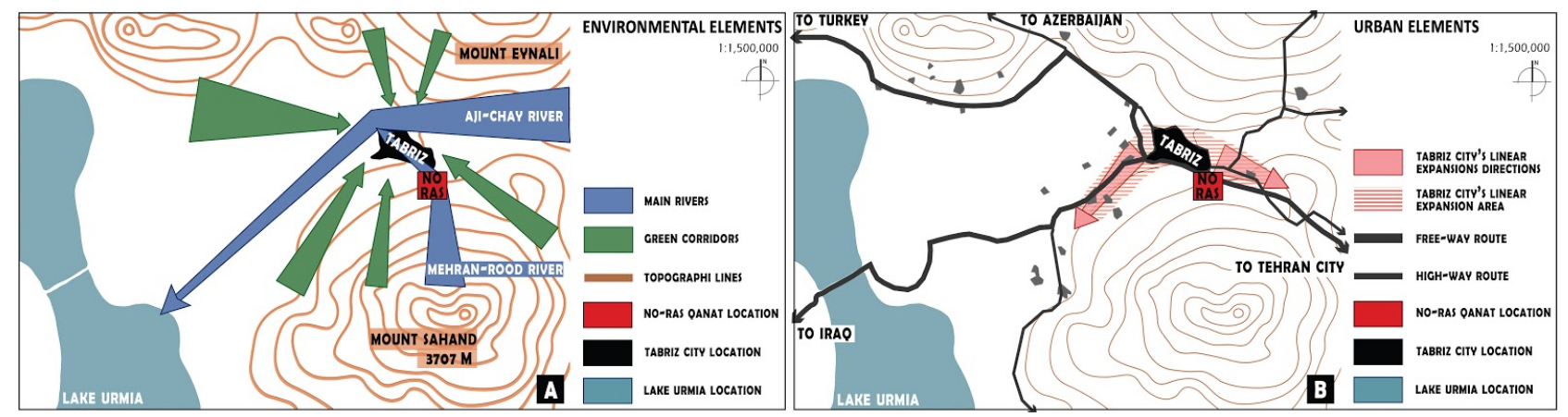

Figure 5: Tabriz province analysis in terms of affective environmental and urban elements.

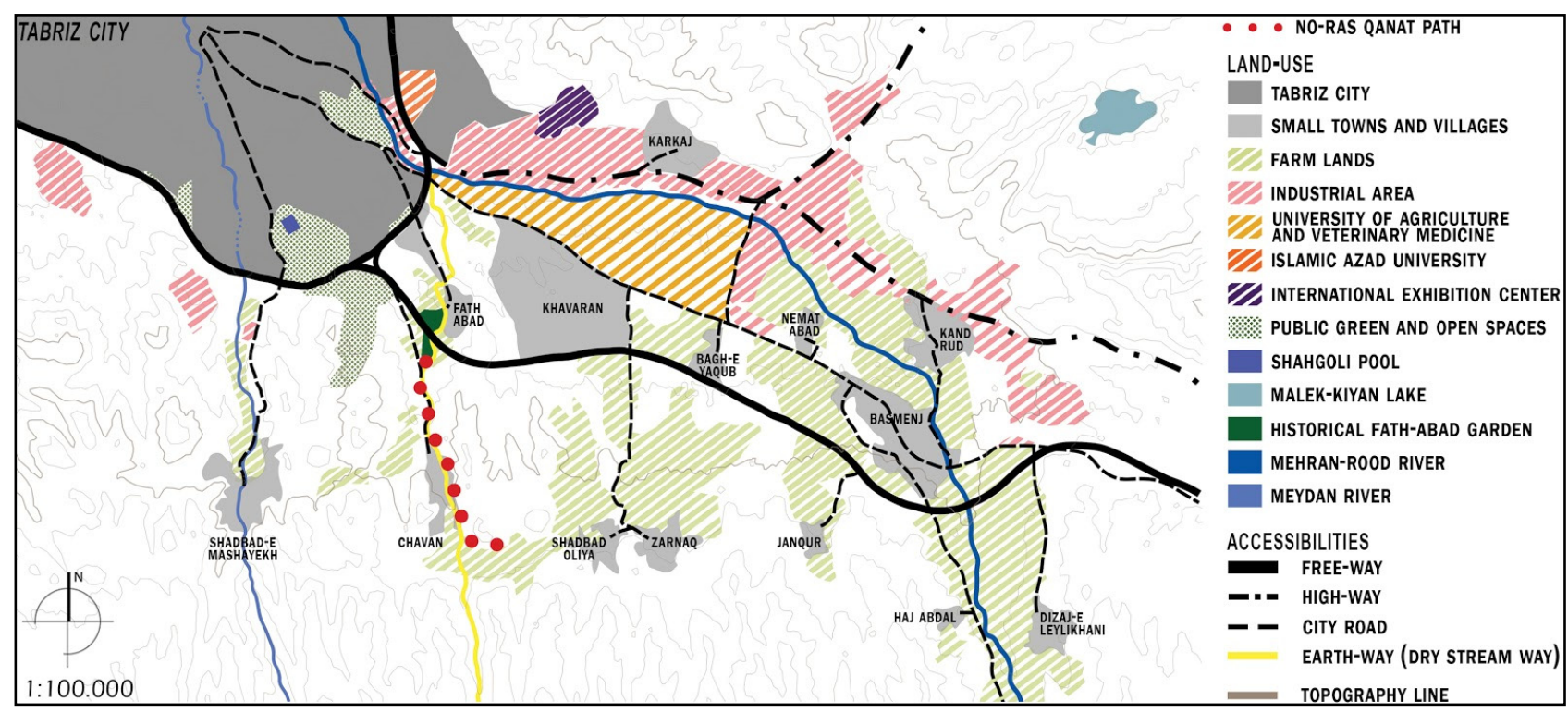

Figure 6: Current land-use of the area of the No-Ras qanat and its neighbourhood.

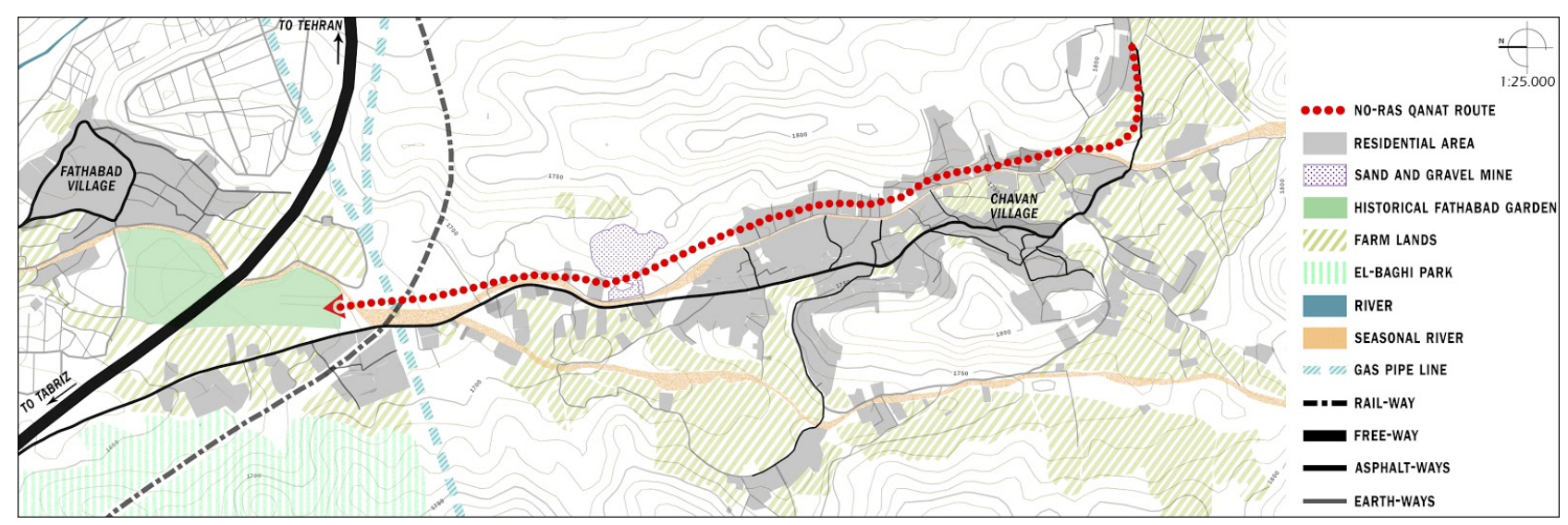

Figure 7: Current land-use of the area of the No-Ras qanat. 
The ground-truthing conducted in 2019 also indicates that both the height and the width of the No-Ras gallery have decreased dramatically during the last 30 years. The main reason for this is the deposition of sediments over time. Generally, some accessible parts of the qanat gallery are inspected two times a year by the moqanni and his team, and when necessary cleaning and dredging need to be done.

Both the gradual loss of skilled artisans and the lack of accessibility to the wells are making these activities barely impossible to be done.

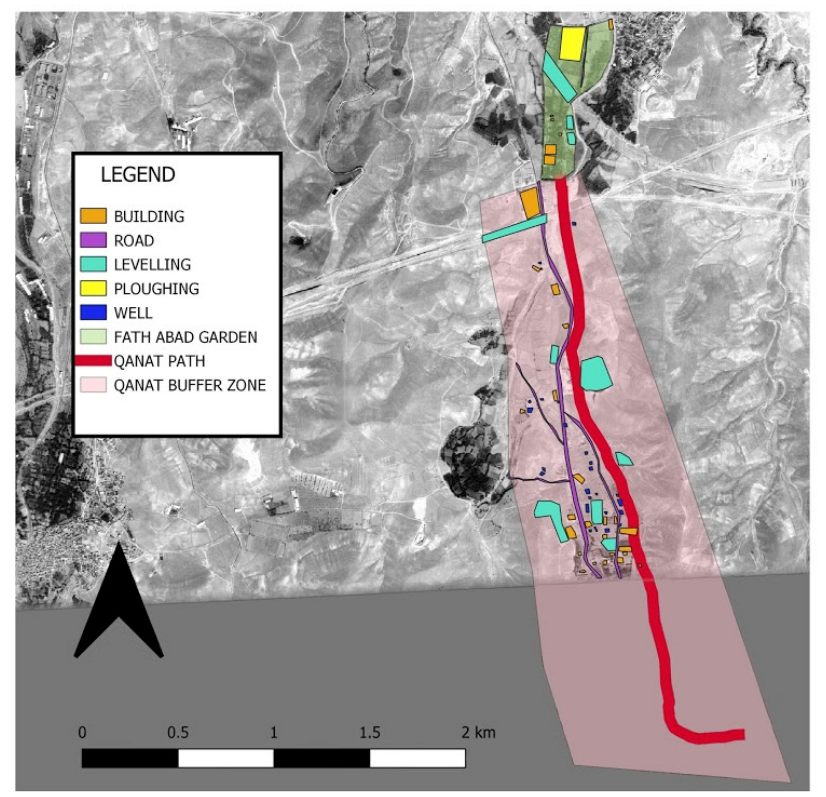

2003

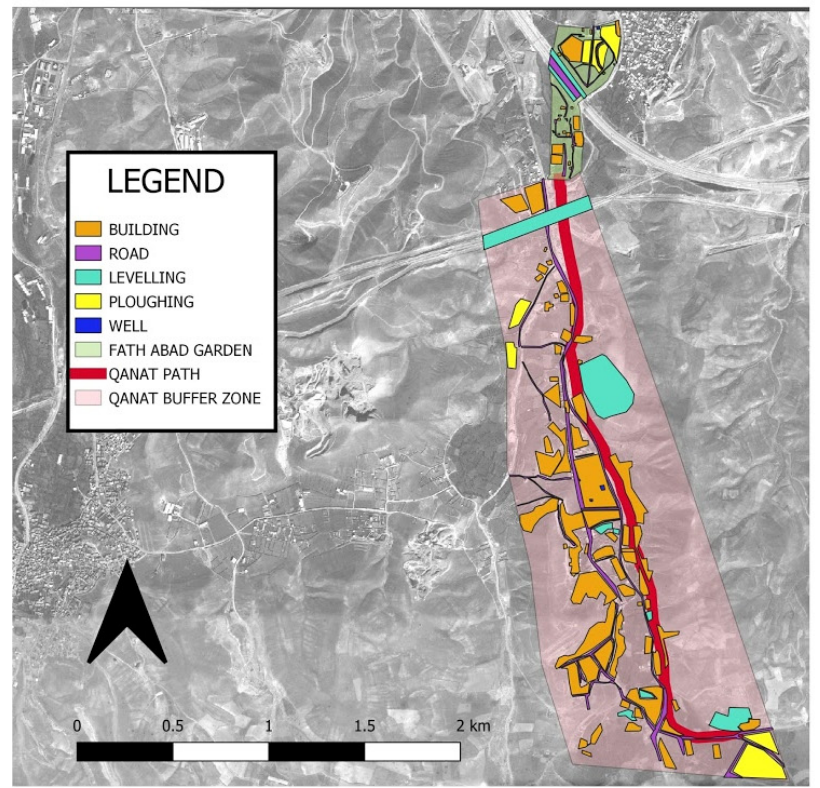

2013
With regard to the conservation and promotion of the NoRas qanat, as an element of heritage, following the registration of the FathAbad garden in the Iran National Heritage List in 1996, the Historical Garden Mansion (Fig. $10 \mathrm{a}$ and $10 \mathrm{~b}$ ) along with part of its surrounding garden have been restored (Fig. 10c). The restorations took place in a non-invasive way, respecting the architectural layout and the original decorations.

Some restorations, however, were conducted in an invasive manner, modifying the original layout of the FathAbad Garden (Fig. 11).
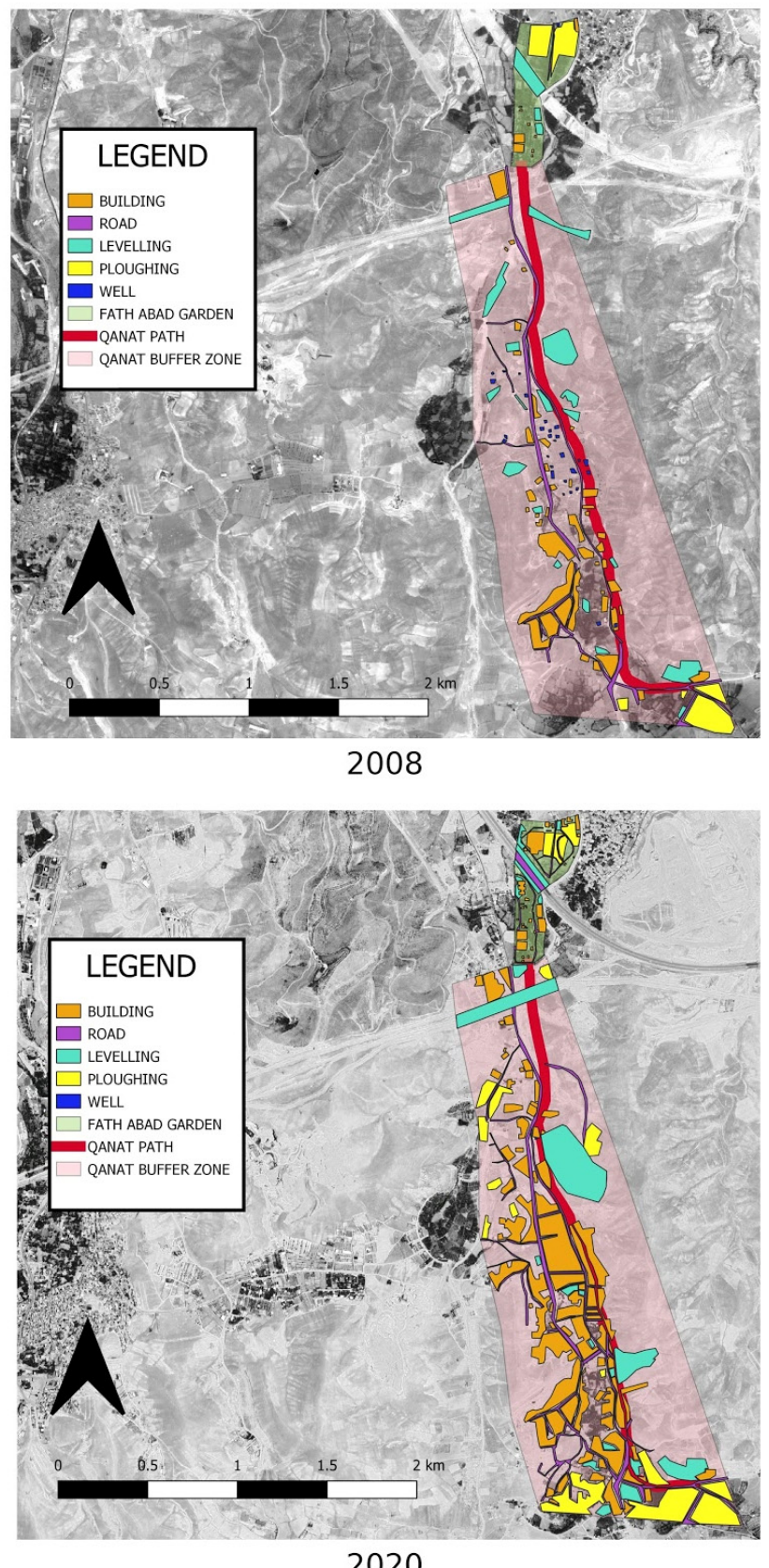

2020

Figure 8: Multi-temporal development of the damages to the No-Ras qanat and its buffer zone.

In particular, the main path leading to the mansion was mostly characterized by a long meadow, flanked on both sides by trees and with a water channel in the centre interspersed with fountains (Fig. 11a). Following the registration of the FathAbad Garden in the National Heritage List major restoration works had been undertaken including the replacement of the meadow with a self-locking pavement, the creation of small walls at 
both sides of the water channel and the construction of wooden fences (Fig. 11b and 11c).

\subsection{Perception and awareness analysis}

We first analyzed the multi-faceted population living within the No-Ras buffer zone or close to it. Five main groups have been identified based on the economic and social factors:

1) LOCAL FARMERS. The native people of the area consist of old farmers. Their number has gradually reduced due to their migration to large cities such as Tabriz. Until the early 2000s, their lands were not connected to the municipal water system and their subsistence relied upon the use and maintenance of qanats. This makes them among the most informed group of the importance of the preservation of the qanats.

2) OLD IMMIGRANTS FARMERS. This group represents the majority of the population in the region, especially in the village of Chavan. They include old immigrants whose main jobs are agriculture, gardening, and animal husbandry. They also have a good understanding of the value of qanats which they have extensively used for the irrigation of cultivated lands and gardens as well as the supply of water for their livestock.

3) NEW IMMIGRANTS. This group includes people who have migrated from Tabriz and other major cities to Chavan and FathAbad areas in the last ten years due to the advantages of these areas, the lower cost of land and the greater space. Although they live in these areas, most of these people have kept their jobs in Tabriz and therefore, they have no direct relationship and interest in the issues related to the qanat. The majority of them have no information about qanats in general.

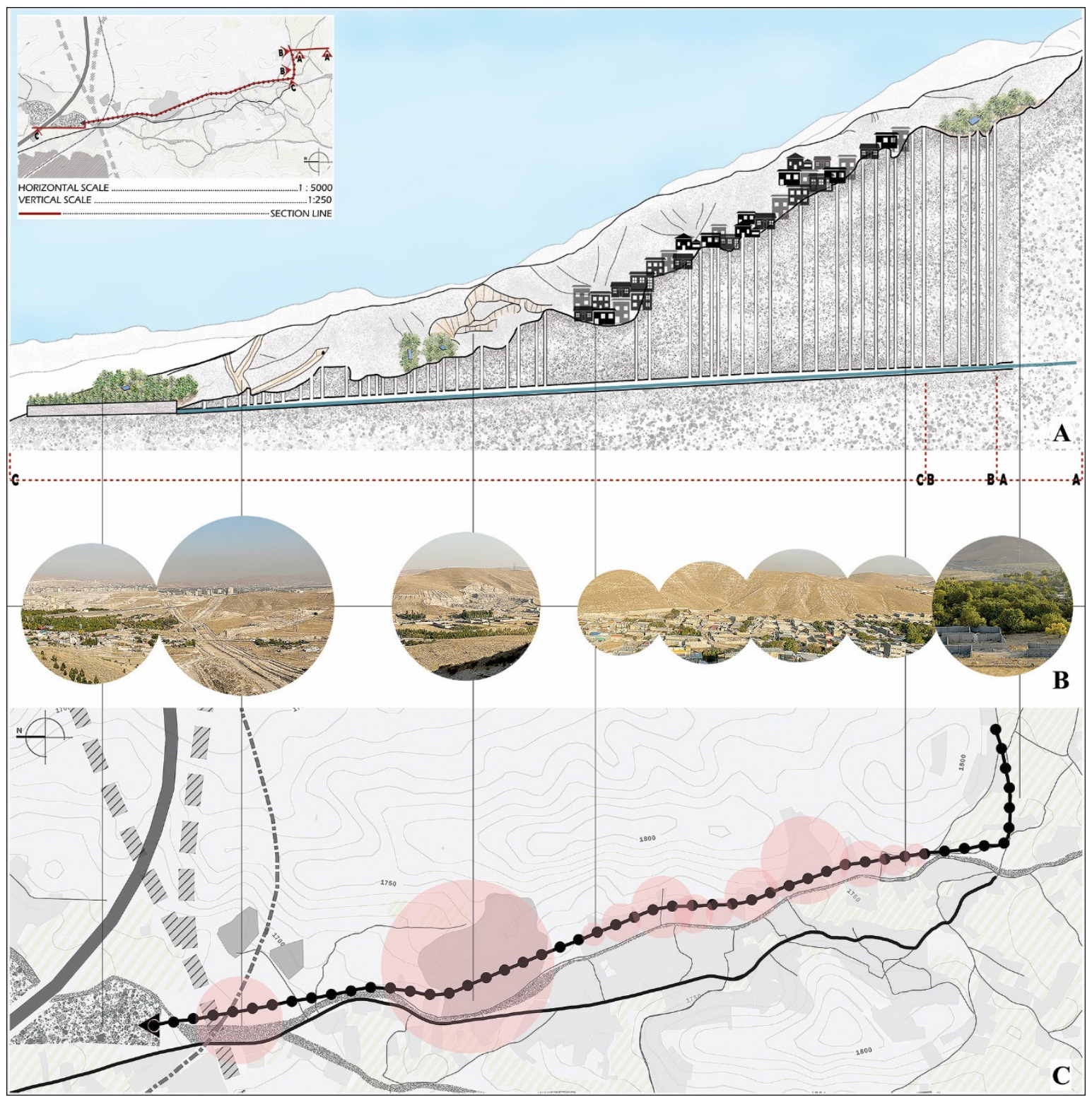

Figure 9: Current damages and structural failures along the No-Ras qanat. 

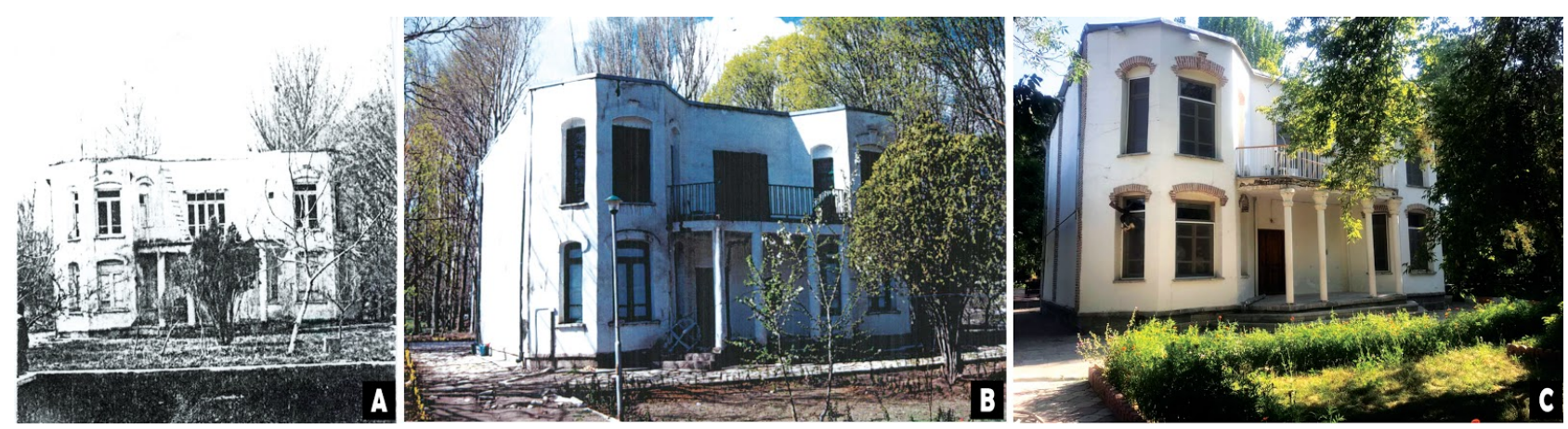

Figure 10: FathAbad Historical Garden Mansion. 10A) The mansion in 1972; 10B) The mansion at the time of the registration of the FathAbad Garden in the list of National Monuments in 1996 (FathAbad garden's national monuments registration document, 2001); 10C) The mansion after the restoration (photo taken in September 2020 by F. Zavvari).
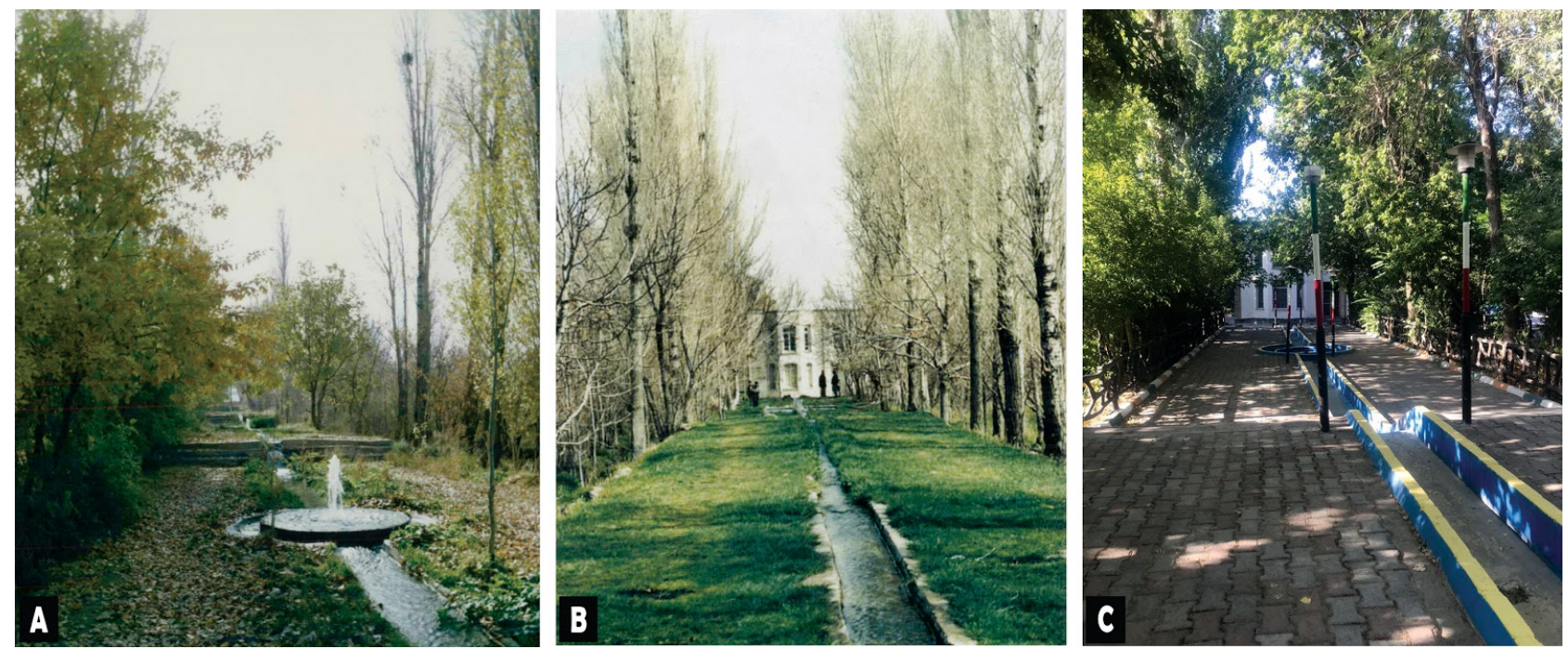

Figure 11: FathAbad Historical Garden main path. 11A) The garden before restoration in 1994 (FathAbad garden's national monuments document, 2001); 11B) The garden at the time of its registration within the list of National Monuments (FathAbad garden's national monuments document, 2001); 11C) After the restoration (photo taken in September 2020 by F. Zavvari).

4) FACTORIES EMPLOYEES. This group includes people employed in small factories such as stone cutting, construction, warehouses, sand and gravel mines etc. Most of these people are commuter workers. The importance of this group for our research lies in the fact that through their work (deep excavations, unloading industrial waste, the passage of heavy vehicles, etc.) they modify and damage the structure of the qanat.

5) NEW OWNERS. These people purchased lands within the qanat buffer zone during the last ten years, to build private villas. Given their remarkable size, part of these lands was also turned to small agricultural fields and fruit planting for personal use, as well as leisure facilities such as swimming pools. What makes this group relevant for the research is that each owner has one or two deep or semi-deep wells in their lands which are often part of the qanat structure or have been illegally dug to get the water from the qanat gallery. Moreover, the construction of the villas and related structures near the wells triggered major stability issues, while the use of the wells for sewage discharge may pollute the qanat water.
The interviews revealed two main interpretations of the qanats among the five groups. Group 1 (Local farmers) and group 2 (Old immigrant farmers), which primarily benefit from the water supply of the qanat, have in-depth knowledge of the function, maintenance as well as some historical information. Their commitment towards the preservation of the qanat is so strong that many of them organized protests (together with the FathAbad garden owner) against the heavy damages caused by the sand and gravel mine (which unfortunately were ignored).

Although far from the monumental qanat of central Iran, groups 1 and 2 perceive No-Ras as a cultural asset that is part of the region's history. They also recognize how modern technologies together with climate change strongly affect the abandonment and destruction of these hydraulic infrastructures. They also believe that specific actions, including in compliance with the laws in force, are carried out to preserve the qanat.

Groups 3 (New immigrants), 4 (Factories employees) and 5 (New owners) have a completely different view. Most of them have poor or no information on the overall function, economic benefits and history of qanats. The few who have the information about the No-Ras and other qanats, consider them an obsolete technology, unsuitable for modern economic and social challenges. Some interviewee (Group 3) stressed the fact that the existence 
of the No-Ras and other qanats represents a barrier for the urban development of the region. While acknowledging in a few cases, the relevance of some qanats (mainly from the Yazd region) as national cultural heritage, none of them recognize the No-Ras as such.

This analysis highlighted that there is still a part of the population that recognizes both the economic and cultural value of the No-Ras qanat (Groups 1 and 2). These people can be important drivers in communicating the importance of qanats to the remaining groups and in mitigating the current destructive processes. Indeed, as for the remaining groups, the main issue is the lack of knowledge towards the function, economic benefits and history of qanats. In addition, most of them also ignore the negative impact of some of the technologies used to replace them (such as dams).

\section{Discussion}

The territorial and land-use analysis offered a detailed picture of the changes in the Tabriz region and their impact on the No-Ras qanat, thus allowing us to answer the first research question. The gradual shifts in territorial occupation and land-use are a direct indicator of widespread anthropization. Among others, human activities included farmlands expansion, the sharp increase of the residential complexes and industrial areas, as well as the growing network of roads and highways. Altogether, these had a profound impact on the environmental, social and economic systems of Tabriz and the No-Ras qanat.

This regional scale was then integrated, following a multiscalar approach, with a detailed multi-temporal damage assessment and structural analysis of the No-Ras qanat. These allowed us to tackle the second research question regarding the issues and threats that affected the massive hydraulic structure during the recent past. Figure 8 showed the dramatic boost in the damages to the No-Ras qanat due to the heavy anthropization between 2003 and 2020. Buildings and roads represent the major actions damaging the qanat and its buffer zone in this period, although other threats such as ploughing and levelling must be considered.

Our analysis confirmed that economic development in the region over the last 20 years had the greatest effect in terms of threats and damages to the area of the No-Ras qanat and the surrounding environment. The more people move out from the cities to the peripheries, the more land is converted to buildings and roads. The gradual increase of damages to the qanat and its buffer zone, also heavily affected the internal structure of the qanat including the wells, the gallery and the outlet. Construction of roads and the passing the heavy trucks and cargo vehicles put pressure on the internal structure of the qanat. Therefore both the gallery and the walls would fall off and block the water flow. Moreover, while the residents' need to access water made them drill wells, in our case study, it led to water shortage of the No-Ras qanat which is one of the impacts of being abandoned.

The emerging issue of the abandonment of the No-Ras qanat was tackled by the third research question by means of interviews with the different communities living in the area. This last analysis highlighted a clear-cut division between local farmers living in, with and for the land and other groups such as immigrants and new owners. The deep understanding of the current issues specifically the water reduction in the qanat is mostly relevant to human conduct that directly influences their cultivations. As well as the strong commitment towards the safeguarding of the farmlands as their economical resources make the first group the most suitable to convey the importance of the No-Ras qanat as a traditional hydraulic tool and local heritage. To be fully efficient, this group needs to be supported by institutions and organizations.

In the conclusive section, we provide tailor-made recommendations (fourth research question) to foster collaborations and preserve and re-use the No-Ras qanat.

\section{Conclusion and recommendations}

The Qanat is a multifaceted structure in which cities and villages' stability and consistency depend on its existence both in the past and now.

The multifaceted nature of the Qanat refers to its essential function, which is supplying water. However, while always considered as a valuable thing, the meaning of water is more understandable when it becomes hard to reach.

In this conclusive section, we answer the fourth research question by offering recommendations to mitigate the issues raised at the beginning of the paper, based on the results provided by the integrated methodology. These recommendations are addressed to different target groups including national and local authorities, NGOs, the local community (i.e. the five groups identified) and the local, national and international research community and other private stakeholders such as cultural heritage organizations and agricultural organizations.

\subsection{Recommendations for mitigating water shortage (Issue 1)}

Our multidisciplinary approach has shown (see 5.1 and 5.2) a substantial change in the land-use over the entire Tabriz area, both in the form of population growth and urban sprawl, an increase of ploughed areas, alongside the growing interest in drilling deep and semi-deep wells. This phenomenon resulted in an increasing water shortage, which was mitigated by the local institutions through the construction of modern water supply systems. However, their mitigation effects will decrease in the medium and long-term as confirmed by numerous studies (Marchetti, Bitelli, Franci, \& Zaina 2020; Wieland \& Muller, 2009), bringing back the issue of water shortage to the fore. Moreover, most of these hydraulic infrastructures are already providing substantial environmental and social problems, such as loss of biodiversity, pollution or soil degradation. The millennial history of qanat demonstrates its long-term use. Also, qanats represent a clean and perennial water supply system. While a detailed analysis of the cost and the water flow compared to that of the existing hydraulic infrastructures will better frame the benefits of qanats, their low environmental impact, the cultural value and the great efficiency are reason to consider them as a traditional system to mitigate water shortage and at least partially replace modern infrastructures.

In this regard, the Regional Water Company and the Agricultural Jihad Organization should conduct/promote 
detailed assessments to compare the cost/benefits of current hydraulic infrastructure and qanat (including the No-Ras), in the region. If they will result in a successful water supply method, a collaborative and sustainable water management protocol should be developed involving national and local authorities as well as farmers and other stakeholders.

\subsection{Recommendations for mitigating mismanagement and lack of documentation (Issue 2)}

This paper revealed a substantial lack of management and documentation of qanats by official bodies in the Tabriz region. Recommendations for mitigating these shortcomings should be addressed to two major stakeholders meaning governmental bodies and local institutions. Management strategies of Iranian qanats at the institutional level remained poorly developed until 2011 due to the higher interest in modern water supply systems (dams, water pumping etc.). Despite the formal protection provided by the national law, this lack of interest caused the gradual abandonment and destruction of qanats throughout the country.

Since 2011, the growing issue of water shortage and the recognized cultural value of some of the qanats, fostered the collaboration between the Ministry of Cultural Heritage, Tourism and Handicrafts, and the Agricultural Jihad Ministry, to improve the documentation and management of several qanats in central Iran.

This successful collaboration should be also extended to the rest of the country. In addition, the analysis provided in this paper should be also applied to other qanats to have a clear assessment of the state of preservation of each qanat. These assessments may be critical for future policy-makers to improve current legislation as well as to better orient investments. Public calls funded by national or regional bodies may foster the participation and involvement of different public and private research institutes in this kind of studies.

\subsection{Recommendations for mitigating loss of technical skills (Issue 3)}

The integrated analysis showed that during the last 20 years, there has been a substantial land-use change in the No-Ras qanat area connected with a slow decrease of local farmers and craftsmen specialized in the construction and maintenance of qanat (moqanni and others). In particular, being a moqanni is a kind of job usually inherited from father to son or continued among family members. The territorial, land-use and demographic changes in the region highly affected this historical and social process. As highlighted by the perception and awareness analysis some farmers still keep partial technical skills. Moreover, local organizations such as the Regional centre of Agriculture Jihad work to support farmers and landowners in the maintenance and use of qanat also integrating modern clean and noninvasive techniques. The joint collaboration of these two groups has proved to be a best practice in other regions of the country including Yazd, Isfahan, and Semnan and could be successfully applied also in the Tabriz region. In addition, specific funds could be allocated both at the national and regional level for training courses for Moqannis.

\subsection{Recommendations for improving the lack of awareness (Issue 4)}

A large part of the current local residents showed a remarkably low level of awareness towards the qanats as both an important hydraulic system and part of the national heritage. This fact, coupled with the lack of NGOs or other groups promoting and communicating the importance of qanats will lead to a steady drop in the people's perception and commitment toward their preservation and use over the next decades. This situation is further complicated by poor communication between academia and society. This is demonstrated by the low impact of numerous academic research on the subject, together with the inscription of Yazd qanats on the UNESCO WHL, on the population.

As already suggested in the discussion, also in this case it is the local farmers who play a pivotal role. Therefore, we suggest increasing the synergy between universities and local farmers, possibly with the support of the government, in creating projects and associations for the protection and communication of the importance of qanat. In this regard, capacity-building projects such as those promoted by the Erasmus+ KA2 scheme of the European Union represent a well known and successful strategy to start this kind of collaboration. Field visits, meetings, training, production and distribution of videos, brochures and booklets to explain the relevance of qanat and compare them with other water supply sources such as deep wells and dams to learn their advantages and disadvantages could be among the activities to be carried out.

\subsection{Recommendations to increase the perception of qanat as cultural heritage (Issue 5)}

The perception and awareness analysis (5.4) allowed us to detect a considerable difference in the perception of qanats as heritage amongst the five identified groups. According to the semi-structured interviews, only two groups (who directly benefit from the qanat) perceived the No-Ras qanat as a heritage worth preserving, while other groups, not having any or enough information, see the qanat as an obstacle for urban development.

The results of this study have several practical implications on the necessity to equip local residences with sufficient and up-to-date information about their heritage. The cultural heritage value of qanat should be first recognized, accepted and protected by the society to which they belong. Raising awareness and promoting qanat as cultural heritage can be done by involving several stakeholders including the government, NGOs, universities and research centres, local communities and private entrepreneurs. In the case of No-Ras qanat, we suggest a stronger collaboration between the regional Jihad Agricultural Organization and the regional organization of cultural heritage, tourism, and handicraft, local universities and communities through activities and projects. Collecting the oral history and historical documents (photos, documents etc.) about the No-Ras qanat, setting up of tailor-made communication strategy through videos, ad-hoc websites, brochures and booklets are amongst them. Moreover, we propose the educational sectors introduce cultural heritage and its importance to the young generation by engaging them in site visiting, 
lectures and workshops not only to promote awareness, even to encourage them to participate in heritage conservation.

\section{Future Perspectives}

While the present research mostly provided assessments on the land-use, state of preservation of the No-Ras qanat, and community awareness and engagement, future researches and projects should move to the "next step", meaning designing and conducting fieldwork projects keeping in mind the recommendations proposed in this paper. These projects should integrate two different types of approaches:

1) Bottom-up. By applying community-based researches involving local farmers, future projects should promote a wide range of activities aiming at raising awareness toward the importance of qanat as a shared economic resource and local heritage as well as for enhancing social cohesion and cultural identity.

2) Top-down. Future projects should not avoid the involvement of local and national authorities. For example, consultation between policy-makers and local stakeholders will be crucial to improve the current legislation for the protection and maintenance of qanats at the national level.

In this regard, best practices on the integration of bottomup and top-down approaches have been already successfully tested for other traditional hydraulic systems in England (Cook \& Williamson, 2007; Historic England, 2017), Spain (Civantos \& Garcia 2015) and Italy (Bove, Branduini, \& Molina, 2020; Branduini, 2020).

Besides the practical application, future studies must also frame the preservation and reuse of qanats within larger debates including climate change. Indeed, qanats may play an important role in the mitigation of hazards caused by both climate change and modern human-made infrastructures such as dams.

\section{Acknowledgements}

The authors wish to acknowledge the manager of the FathAbad Garden and the moqanni of the No-Ras qanat for their help and support during the fieldwork and the numerous information provided, including photos and videos.

\section{References}

Abbasnejad, A., Abbasnejad, B., Derakhshani, R., \& Hemmati Sarapardeh, A. (2016). Qanat hazard in Iranian urban areas: explanation and remedies. Environmental Earth Sciences, 75, 1-14. https://doi.org/10.1007/s12665-016-6067-6

Al-Kashani, A. (1968). History of Al-Jaito. Tehran: Mahin Mohbeli. https://doi.org/10.1163/1875-9831_isla_com_0125

Afshar, I. (1971). Rashid Al-Din Fazlullah and Yazd. Tehran: University Press. https://doi.org/10.2307/600182

Agapiou, A., Lysandrou, V. \& Hadjimitsis, D. G. (2017). Optical Remote Sensing Potentials for Looting Detection. Geosciences, 7, 1-18. https://doi.org/10.3390/geosciences7040098

Agapiou, A., Lysandrou, V., \& Hadjimitsis, D. G. (2020). Earth Observation Contribution to Cultural Heritage Disaster Risk Management: Case Study of Eastern Mediterranean Open Air Archaeological Monuments and Sites. Remote Sensing, 12(1330), 1-12. https://doi.org/10.3390/rs12081330

Al Tikriti, W. Y. A. (2002). The South-East Arabian Origin of the Falaj System. Proceedings of the Seminar for Arabian Studies (Vol. 32), 117-138. Turnout: Brepols.

Balali, M. R., Keulartz, J., \& Korthals, M. (2009). Reflexive water management in arid regions: the case of Iran. Environmental Values, 20, 91-112. https://doi.org/10.3197/096327109X404807

Beekman, C. S., Weigand, P., Pint, J. J., Zotz, G. E., \& Pin, S. (1996). El qanat de La Venta: sistemas hidráulicos de la época colonial en el centro de Jalisco. Jalisco: Secretaría de Cultura Gobierno del Estado de Jalisco.

Bensi, N. S. (2020). The Qanat System: A Reflection on the Heritage of the Extraction of Hidden Waters. In C. Hein (ed.) Adaptive Strategies for Water Heritage, 40-57. Berlin: Springer.

Bove M., Branduini P. \& Molina G. (2020). La Marcita. Storia di un'antica invenzione contadina che parla di futuro all'agricoltura italiana. Magenta. Retrieved November 25, 2020, from http://ticinobiosource.it/wpcontent/uploads/2018/12/Pubblicazione-Marcite-WEB.pdf

Branduini, P. (2020). Engagement, participation and governance of urban agricultural heritage. In L. Scazzosi \& P. Branduini, (Eds), AgriCultura. Urban agriculture and the heritage potential of agrarian landscape, 45-62. Berlin: Springer. https://doi.org/10.1007/978-3-030-49012-6

Briant, P. (2001). Irrigation et drainage dans l'Antiquité, qanats et canalisations souterraines en Iran, en Égypte et en Grèce. Paris: Thotm Éditions.

Civantos, J.M. \& Garcia, M.T. (2015). MEMOLA project. Mediterranean Mountainous Landscapes: an historical approach to cultural heritage based on traditional agrosystems. Post-Classical Archaeologies, 5, 347-356. https://memolaproject.eu/node/1873.

Cook, H. \& Williamson T. (eds) (2007). Water Meadows: History, Ecology and Conservation, Windgather Press. Retrieved November 25, 2020, from https://historicengland.org.uk/images-books/publications/conserving-historic-watermeadows/heag176-conserving-water-meadows/ 
Cunliffe, E. (2014). Archaeological Site Damage in the Cycle of War and Peace: A Syrian Case Study. Journal of Eastern Mediterranean Archaeology and Heritage Studies, 2, 229-247. https://doi.org/10.5325/jeasmedarcherstu.2.3.0229

Cunliffe, E. (2016). Sixty Years of Site Damage in the Carchemish Region. In T.J., Wilkinson, E. Peltenburg \& E.B. Wilkinson (Eds.), Carchemish in Context, 203-214. Oxford: Oxbow.

Dalley, S. (2013). The mystery of the Hanging Garden of Babylon: an Elusive World Wonder Traced. Oxford: OUP.

De Martonne, E. (1941). Nouvelle carte mondiale de l'indice d'aridité. Annales de géographie, 288, 3-20.

De Chatel, F. (2005). Water of the Prophets. Amsterdam: Uitgeverij Contact.

Ebadati, N., \& Hosseini, A. H. (2018). Quality assessment of qanat water for drinking and agricultural uses in Tehran. International Journal of Hydrology, 2(2), 198-203. https://doi.org/10.15406/ijh.2018.02.00069.

Estaji, H., \& Raith, K. (2016). The role of Qanat and irrigation networks in the process of city formation and evolution in the central Plateau of Iran, the Case of Sabzevar. In F.F. Arefian \& S.H. Moeini (Eds.), Urban change in Iran, 9-189. Berlin: Springer. https://doi.org/10.1007/978-3-319-26115-7_2

FathAbad Garden National Registration File in the List of National Monuments of Iran (2001). Tehran, Library and Documentation Center of the Cultural Heritage. Tabriz: Tourism and Handicrafts Organization of East Azerbaijan.

Gerrard, C., \& Gutiérrez, A. (2018). The Qanat in Spain: Archaeology and Environment. In J. Berking (ed.), Water Management in Ancient Civilizations, 197-226. Berlin: Humboldt. https://doi.org/10.17171/3-53

Goblot, H. (1979). Les Qanats, une technique d'acquisition de l'eau. Paris-La Haye: Ecole des hautes sciences sociales.

Haeri, M. (2007). Qanat in Iran. Tehran: Institute of cultural research.

Hammer, E., Seifried, R., Franklin, K. \& Lauricella, A., (2018). Remote assessments of the archaeological heritage situation in Afghanistan. Journal of Cultural Heritage, 33, 125-144. https://doi.org/10.1016/j.culher.2017.12.008

Hosseini, S. A., Shahraki, S. Z., Farhudi, R., Hosseini, S. M., Salari, M., \& Pourahmad, A. (2010). Effect of urban sprawl on a traditional water system (Qanat) in the City of Mashhad, NE Iran. Urban Water Journal, 7(5), 309-320. https://doi.org/10.1080/1573062X.2010.484497

Historic England (2017). Conserving Historic Water Meadows. Swindon: Historic England.

Hu, W., Zhang, J., \& Liu, Y. (2012). The qanats of Xinjiang: historical development, characteristics and modern implications for environmental protection. Arid Land, 4(2), 211-220. https://doi.org/10.3724/SP.J.1227.2012.00211

Hütteroth, W. (1990). Villages and tribes of the Gézire under the early Ottoman administration (16th century). A preliminary report. Berytus, 28, 179-184.

ICCROM, (2016). A Guide to Risk Management of Cultural Heritage. Ottawa: Canadian Conservation Institute.

ICOMOS, (2000). Heritage at Risk: ICOMOS World Report 2000 on Monuments and Sites in Danger. Paris: ICOMOS.

Jomehpour, M. (2009). Qanat irrigation systems as important and ingenious agricultural heritage: case study of the qanats of Kashan, Iran. International Journal of Environmental Studies, 66(3), $297-315$. https://doi.org/10.1080/00207230902752629

Kabir, M. (2008). Interaction of design and nature in Fath Abad Garden of Tabriz. Golestan-e Honar, 11, 48-54

Kabir, M. (2010). Rereading the original evolution plan of Fath Abad village in Tabriz. Maskan va Mohite, 140, 39-50.

Khaneiki, M. (2019). Territorial Water Cooperation in the Central Plateau of Iran. Berlin: Springer. https://doi.org/ 10.1007/978-3-030-01494-0

Lasaponara, R., \& Masini, N. (2012) Remote sensing in archaeology: from visual data interpretation to digital data manipulation. In R. Lasaponara \& N. Masini (Eds.), Satellite Remote Sensing: A New Tool for Archaeology, 17-63. Berlin: Springer. https://doi.org/ 10.1007/978-90-481-8801-7

Lauricella, A., Cannon, J., Branting, S., \& Hammer, E. (2017). Semi-automated detection of looting in Afghanistan using multispectral imagery and principal component analysis. Antiquity, 91, 1344-1355. https://doi.org/ 10.15184/aqy.2017.90

Lightfoot, D. R. (1997). Qanats in the Levant: hydraulic technology at the periphery of early empires. Technology and Culture, 38(2), 432-434. https://doi.org/10.2307/3107129

Lightfoot, D. R. (2000). The origin and diffusion of qanats in Arabia: new evidence from the northern and southern peninsula. Geographical Journal, 166(3), 215-226. https://doi.rog/10.1111/j.1475-4959.2000.tb00021.x

Lofrano, G., Carotenuto, M., Maffettone, R., Todar, P., Sammataro, S., \& Kalavrouziotis, K. (2013). Water collection and distribution systems in the Palermo plain during the middle ages. Water, 5(4), 1662-1676. https://doi.org/10.3390/w5041662

Lopez, P.J.M. (2016). Integrated Risk Assessment for Cultural Heritage Sites: a Holistic Support Tool for Decision-making. 
Unpublished PhD thesis. IMT School for Advanced Studies, Lucca. http://e-theses.imtlucca.it/195/

Luo, L., Wang, X., Guo, H., Liu, C., Liu, J., Li, L., \& Qian, G. (2014). Automated extraction of the archaeological tops of qanat shafts from VHR imagery in Google Earth. Remote Sensing, 6(12), 11956-11976. https://doi.org/10.3390/rs61211956

Maleki, A., \& Khorsandi aqaei, A. (2016). Qanat in Iran (the case study of Tehran qanats), urban processing and planning company, Tehran: University Press. https://doi.org/10.4000/abstractairanica.11302

Marchetti, N., Bitelli, G., Franci, F., \& Zaina, F., (2020). Archaeology and Dams in South-eastern Turkey: Post-Flooding Damage Assessment and Safeguarding Strategies on Cultural Heritage. Journal of Mediterranean Archaeology, 33, 29-54. https://doi.org/10.1558/jma.42345

Marchetti, N., Curci, A., Gatto, M.C., Muhl, S., Nicolini, S., \& Zaina, F. (2019). A multi-scalar approach for assessing the impact of dams on the cultural heritage in the Middle East and North Africa. Journal of Cultural Heritage, 37, 17-28. https://doi.org/10.1016/j.culher.2018.10.007

Ministry of Energy (2005). The reserves of Iran water recourse. Tehran: Ministry of Energy.

Ministry of Energy (2018). Guideline for determining the core and buffer zones of the wells and qanats. Tehran: Ministry of Energy.

Minovi, M., \& Afshar, I. (1972). Rashid-al-Din Fazl-Allah, Waqf-nāma-ye Rab -e rašidi, Tehran: University Press.

Mostafaeipour, A. (2010). Historical background, productivity and technical issues of qanats. Water history, 2(1), 61-80. https://doi.org/10.1007/s12685-010-0018-z

Palumbo, G., (2000). Threats and Challenges to the Archaeological Heritage in the Mediterranean. In J.M., Teutonico \& G. Palumbo (Eds.), Management Planning for Archaeological Sites, 3-13. Los Angeles: The Getty Conservation Institute.

Petrushevsky, P. (1978). Agriculture and agrarian relations in Mongol Mongol Empire, Iran, Tehran: Nil Press.

Richardson, B. F. (2011). Techniques of Detecting and Delineating Archaeological Site Destruction Using High Resolution Satellite Imagery: An Iraq Case Study. Paper presented at the ASPRS 2011 Annual Conference Milwaukee, Wisconsin. May 1-5, 2011.

Saberi, R. (2016). Environmental, economic and social consequences of the destruction of qanats. Geography, 75, $42-57$.

Salvini, M. (2001). Pas de Qanat en Urartu. In P. Briant (ed.), Irrigation et drainage dans l'antiquité, qanats et canalisations souterraines en Iran, Egypte et en Grèce, 190-210, Paris: Thotm éditions. https://doi.org/10.4000/etudesrurales.126

Shahabadi, A. \& Olfati, S. (2009). Qanats in Ecology. Geography, 3, 28-39.

Shoup, D. (2006). Can Archaeology Build a Dam? Sites and Politics in Turkey's Southeast Anatolia Project. Journal of Mediterranean Archaeology, 19(2), 231-258. https://doi.org/10.1558/jmea.2006.v19i2.231

Steffen, W., Broadgate, W., Deutsch, L., Gaffney, O., \& Ludwig, C. (2015). The trajectory of the Anthropocene: the great acceleration. The Anthropocene Review, 2(1), 81-98. https://doi.org/10.1177/2053019614564785

Stovel, H. (1998). Risk Preparedness: A Management Manual for World Cultural Heritage. Rome: ICCROM.

Strzepek, K. M., Yohe, G. W., Tol, R.S.J. \& Rosegrant, M. W. (2008). The value of the High Aswan dam to the Egyptian economy. Ecological Economics, 66, 117-26. https://doi.org/10.1016/j.ecolecon.2007.08.019

Tabatabaei, M. \& Khazimeh Nejad, H. (2019). Evaluation of protection methods and increase of qanat flow rate in Iran. Abkhan va Qanat, 2(1), 17- 28.

UNESCO, (2010). Managing Disaster Risks for World Heritage, World Heritage Resource Manual. Paris: UNESCO.

Ur, J. (2005). Sennacherib's northern Assyrian canals: new insights from satellite imagery and aerial photography, Iraq, 67(1), 317-345. https://doi.org/ 10.1017/S0021088900001418

Weingartner, H. (2007). Water supply by qanats: a contribution to water shortage in Mediterranean areas. In Proceedings of the 10th International Conference on Environmental Science and Technology, Kos island, Greece (Vol. $57,15551561)$.

White, G.F. (1988). The environmental effects of the high dam at Aswan. Environment: Science and Policy for Sustainable Development, 30, 4-40. https://doi.org/10.1080/00139157.1988.9930898

Wieland, M. \& Mueller, R. (2009). Dam Safety, Emergency Action Plans and Water Alarm System. International Water Power and Dams Construction, 61, 34-38.

Wikander, Ö. (2000). Handbook of Ancient Water Technology. Leiden: Brill.

Wilkinson, T.J., \& Rayne, L. (2010). Hydraulic landscapes and imperial power in the Near East. Water History, 2(2), 115144. https://doi.org/10.1007/s12685-010-0024-1 
Yazdi, A., \& Khaneiki, M. (2017). Qanat Knowledge: construction and maintenance. Berlin: Springer. https://doi.org/ 10.1007/978-94-024-0957-4

Zaina, F. (2019). A Risk Assessment for Cultural Heritage in Southern Iraq: Framing Drivers, Threats and Actions Affecting Archaeological Sites. Conservation and Management of Archaeological Sites, 21, 184-206. https://doi.org/10.1080/13505033.2019.1662653 